\title{
Effects of Nosema apis Zander on inbred New Zealand honey bees (Apis mellifera ligustica L)
}

\author{
LA Malone *, HA Giacon \\ Horticulture and Food Research Institute of New Zealand Ltd, Mt Albert Research Centre, \\ Private Bag 92 169, Auckland, New Zealand
}

(Received 31 May 1996; accepted 16 December 1996)

\begin{abstract}
Summary - Inbred bees (Apis mellifera ligustica) from seven different colonies were dosed individually with spores of Nosema apis and kept in cages. Longevity and spores carried at the time of death were recorded for each bee. The experiment was repeated on three different dates. Control bee longevity varied with experiment date, although the pattern of this response varied from colony to colony. Dosing significantly reduced the lifespans of bees in all but three colonies. Results suggest that bees with superior ability to survive in cages may also withstand $N$ apis infection better. Each cage of dosed bees produced a number of dead bees without detectable spore loads. Survival data comparisons suggest that dosing newly-emerged bees with $N$ apis may result in a relatively fast death for some bees and a slower death for the majority. Spore loads were very variable with no clear relationship to survival time.
\end{abstract}

honey bee / nosema disease / inbred colonies / longevity / seasonal effect

\section{INTRODUCTION}

Nosema apis is a common protozoan pathogen of adult honey bees throughout the beekeeping world (Fries, 1993). Nosema disease has no obvious symptoms and can be difficult to detect without a microscopic diagnosis. However, infected colonies have been shown to produce significantly less honey than healthy colonies and to have a reduced capacity for pollina- tion (Fries et al, 1984; Goodwin et al, 1990; Anderson and Giacon, 1992). The only effective medication is an antibiotic, fumagillin, but concerns about cost and possible residues in honey often preclude its use. It would be desirable to breed bees with resistance to or tolerance of this pathogen. Studies of variation and heritability of honey bee response to $N$ apis (Rinderer and Sylvester, 1978; Sylvester and Rinderer, 1978; Rinderer et al, 1983) have suggested that

${ }^{\star}$ Correspondence and reprints 
improvements could be made by selective breeding.

To determine whether such an approach to nosema control would be feasible in New Zealand, some measure of the variability among bees in response to $N$ apis must first be gained. An earlier study (Malone et al, 1992), in which 13 colonies headed by queen bees from different sources were dosed with $N$ apis spores and then infections monitored in foraging bees for several weeks, suggested that there may be little variability among New Zealand bees in their infection levels after dosing with $N$ apis spores. However, as the queen bees used in that study had been artificially inseminated with pooled semen from drones from all 13 sources, only the queen's contribution to worker genotype differed from colony to colony. In the present study inbred worker bees, derived from queen bees inseminated with semen from their brother drones, were used in an attempt to maximise the genetic differences among bees from different colonies. Furthermore, to reduce variability due to environmental factors, a laboratory-based bioassay method was used.

\section{MATERIALS AND METHODS}

Stocks of Italian race bees were obtained from seven commercial apiaries: four from the South Island of New Zealand (Blenheim, Nelson, Timaru and South Otago) and three from the North Island (Rotorua, Waitomo and New Plymouth). Queen bees raised from each were artificially inseminated with semen from eight to ten of their brother drones and colonies were established from each of these and kept at our apiary in Auckland.

A suspension of $N$ apis spores was prepared by crushing in distilled water the frozen cadavers of bees taken earlier from an infected colony in the apiary. This was purified by filtering through nylon mesh (10 $\mu \mathrm{m}$ pore size) and then three rounds of centrifugation and resuspension in clean water and stored at $4{ }^{\circ} \mathrm{C}$ until use. The concentration of spores in this preparation was determined by a haemacytometer count.
The experiment consisted of bees taken from hives at three different times over a 6-week period: 7 March, 21 March and 5 April 1994, each with one cage of control and one cage of dosed bees from each of seven colonies, with each cage containing 50 bees, ie, a total of 42 cages and 2100 bees. On each date, a frame of sealed brood from each colony was brought into the laboratory and the wax cappings of cells containing newly-emerging adult bees removed, so that the bees would not ingest any wax which may have been contaminated in the hive with $N$ apis spores. At least 100 bees were collected from each frame over a period of about $20 \mathrm{~min}$. Of these 50 were dosed within $1 \mathrm{~h}$ of emergence by force-feeding with $2 \mu \mathrm{L}$ of $60 \%(\mathrm{w} / \mathrm{v})$ sugar syrup containing $2 \mathrm{x}$ $10^{5}$ spores of $N$ apis. A droplet of spore suspension was held at the bee's mouthparts and any bee that did not consume the entire droplet within $1 \mathrm{~min}$ was discarded. The 50 remaining bees were given plain sugar syrup in the same manner to act as controls. Each group of 50 bees was placed in a wooden cage with mesh sides measuring $9 \times 8 \times 6 \mathrm{~cm}$ (internal dimensions), provided with water and sugar syrup $(60 \% \mathrm{w} / \mathrm{v})$ in gravity feeders and some solid food $(0.12$ parts casein, 0.24 parts brewer's yeast and 0.64 parts sucrose mixed with water to a paste). The cages were kept in an incubator at $32{ }^{\circ} \mathrm{C}$ in darkness and checked daily. Food and liquids were replenished as necessary and dead bees were removed, their longevity recorded and their bodies stored frozen. At the end of the experiment, each dead bee (including both dosed and control bees) was thawed and its abdomen removed and crushed thoroughly in $0.5 \mathrm{~mL}$ of water. The number of spores in this suspension, and thus the total number of spores per bee, was estimated from a haemacytometer count made in the following way: for each bee, a $20 \mu \mathrm{L}$ aliquot of suspension was diluted 10 -fold in water and applied to a $0.0025 \mathrm{~mm}^{2} \times 0.1 \mathrm{~mm}$ haemacytometer; spores observed in four large squares were counted and the spore load of each bee (millions of spores per bee) was calculated by multiplying this spore count by 0.3125 . The lowest spore load detectable by this method was thus 312500 spores per bee.

A survival curve, in which the percentage of bees remaining alive in each cage was plotted against the time in days from the beginning of the experiment, was generated for each cage of 50 bees. Mantel-Haenzel (log-rank) tests (Kalbfleisch and Prentice, 1980) were carried out to compare Kayden-Meir estimates of survival 
distribution, $S(t)$, of dosed vs control bees for each combination of date and colony. This test was also used to compare the survival curves of control bees across all colonies and all dates, and dosed bees in a similar fashion. An estimate of the rate of accumulation of $N$ apis spores over the lifetime of each infected bee was made by dividing the number of spores it carried at the time of death by its longevity in days. These rates were then compared by analysis of variance.

\section{RESULTS AND DISCUSSION}

Table I shows the median survival times $\left(\mathrm{LT}_{50}\right)$ for bees from cages representing each combination of colony and date. A diagrammatic representation of these val- ues is shown for both control and $N$ apisdosed bees in figure 1 .

Log-rank tests to compare the control bee survival curves showed that sampling date had a significant effect on bee longevity $(P<0.001$, except for Nelson bees where $P$ $<0.0044)$, although the pattern of this response to season varied from colony to colony (fig 1). For control bees from South Otago, Rotorua and Blenheim, there was no significant difference between the survival curves of bees taken from their hives on 7 March and on 21 March, but significant increases in the $\mathrm{LT}_{50}$ s of these bees (11, 22 and 19 days respectively) on 5 April $(P<0.001)$. A similar increase in longevity

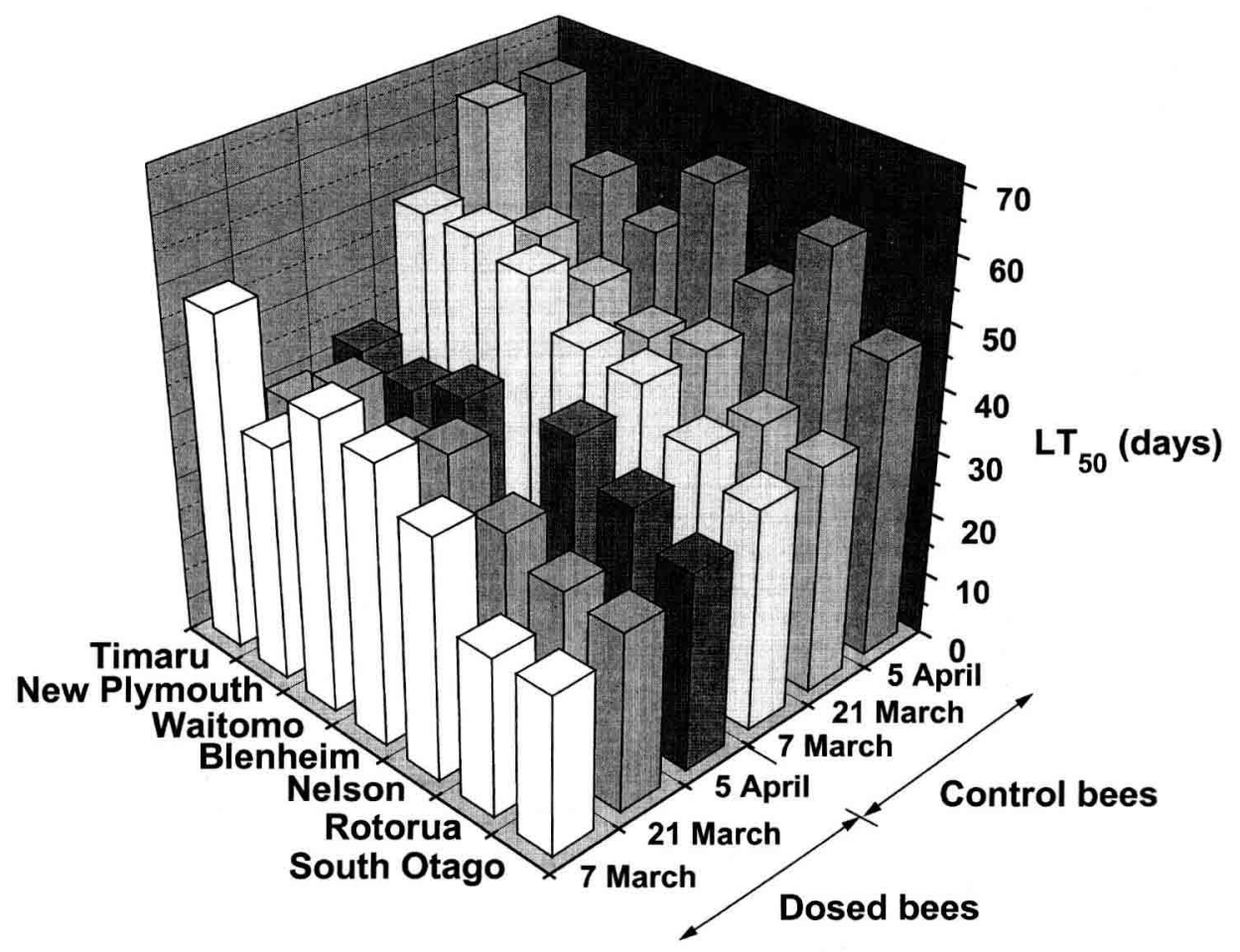

Fig 1. Median survival times $\left(\mathrm{LT}_{50}\right)$ in days of control bees and bees dosed with Nosema apis spores. Bees were taken from seven different colonies at three different sampling dates. $L T_{50} s$ are shown here for ease of presentation, but the statistical analyses used in this study were log-rank tests to compare survival curves. 
Table I. Median survival times $\left(\mathrm{LT}_{50}\right)$ in days for bees taken from seven different colonies at three different times, dosed with Nosema apis spores and kept in cages. Control bees were given a dose of plain sugar syrup. In all but three cases, dosed bees had significantly poorer survival than control bees (log-rank test to compare survival curves, $P<0.00001$ ).

\begin{tabular}{|c|c|c|c|c|c|c|c|c|}
\hline \multirow[t]{3}{*}{ Date } & & \multicolumn{7}{|c|}{ Colony } \\
\hline & & $-\cdots$ & - & - & $-\quad \quad-$ & - & $-\cdot$ & $-\quad-$ \\
\hline & & Rotorua & Nelson & Blenheim & South Otago & Waitomo & Timaru & New Plymouth \\
\hline \multirow[t]{2}{*}{7 March } & Dosed & 25 & 38 & $44^{a}$ & 25 & $46^{b}$ & $53^{c}$ & 37 \\
\hline & Control & 39 & 45 & 46 & 35 & 53 & 55 & 55 \\
\hline \multirow[t]{2}{*}{21 March } & Dosed & 29 & 33 & 40 & 28 & 36 & 34.5 & 41 \\
\hline & Control & 38 & 45 & 43 & 36 & 47 & 67 & 51 \\
\hline \multirow[t]{2}{*}{5 April } & Dosed & 36 & 42 & 5 & 31 & 39 & 38 & 36 \\
\hline & Control & 60 & 49 & 62 & 47 & 51 & 67 & 56 \\
\hline
\end{tabular}

a Survival curves significantly different at $P=0.021$. b Survival curves significantly different at $P=0.056$. ${ }^{c}$ Survival curves significantly different at $P=0.128$.

occurred earlier for bees taken from the Timaru colony; those taken on 21 March or 5 April had significantly better survival (by 12 days) than those sampled on 7 March $(P<$ $0.001)$. In contrast, bees from the Nelson, Waitomo and New Plymouth colonies had survival curves that did not vary significantly with the date of the experiment. As all the bees in this experiment were treated in the same way from emergence onwards, and the colonies from which they were taken had similar food supplies and were all in the same apiary, this result suggests that the colonies were responding in different ways to seasonal events before eclosion and that these differences may have had a genetic basis. It appears that bees from Nelson, Waitomo and New Plymouth did not 'switch' to the production of longer-lived winter bees before the final sampling date, whereas bees from South Otago, Rotorua and Blenheim 'switched' between 21 March and 5 April and bees from Timaru 'switched' at the earliest time, before 21 March.
Log-rank tests comparing survival curves for each date/colony combination showed that dosing with $N$ apis spores very significantly reduced the lifespans of bees $(P<$ 0.00001 ) in all but three cases (fig 1, table I). The exceptions were bees taken on 7 March from three colonies, Blenheim, Waitomo and Timaru ( $P$ values of $0.021,0.056$ and 0.128 respectively). This suggests that the superior ability of Timaru bees to survive in cages, shown among the controls, can sometimes afford them an advantage over other bees in terms of longevity after infection with $N$ apis. However, because this comparative lack of effect of $N$ apis on survival was not evident at the two later dates, it cannot be concluded that this result was due only to genetic differences among the bees.

In each cage of dosed bees, there were a number of individuals that died without a detectable spore load (ie a haemacytometer count of zero) (table II). This may have 
Table II. Comparison of the median survival times $\left(L T_{50}\right)$ in days of Nosema apis-dosed bees only, subdivided into two categories: those recorded as carrying zero spore at the time of death and those carrying a positive number. Fifty bees were taken from each of the seven different colonies at three different times, dosed and kept in cages. The numbers of bees per cage with zero spore counts at death are shown in brackets.

\begin{tabular}{|c|c|c|c|c|c|c|c|c|}
\hline \multirow[t]{2}{*}{ Date } & \multicolumn{8}{|c|}{ Colony } \\
\hline & & Rotorua & Nelson & Blenheim & South Otago & Waitomo & Timaru & New Plymouth \\
\hline 7 March & $\begin{array}{l}\text { Zero } \\
\text { Positive } \\
\text { No bees } \\
\text { with zero } \\
\text { spores }\end{array}$ & $\begin{array}{c}21.5^{a} \\
25 \\
(4)\end{array}$ & $\begin{array}{l}34 \\
39 \\
(8)\end{array}$ & $\begin{array}{c}5 \\
49 \\
(2)\end{array}$ & $\begin{array}{c}21.5 \\
26.5 \\
(6)\end{array}$ & $\begin{array}{c}5 \\
48 \\
(7)\end{array}$ & $\begin{array}{l}53^{a} \\
53 \\
(3)\end{array}$ & $\begin{array}{c}5.5 \\
37.5 \\
(2)\end{array}$ \\
\hline 21 March & $\begin{array}{l}\text { Zero } \\
\text { Positive } \\
\text { No bees } \\
\text { with zero } \\
\text { spores }\end{array}$ & $\begin{array}{c}24.5 \\
29 \\
(6)\end{array}$ & $\begin{array}{l}3.5 \\
33 \\
(6)\end{array}$ & $\begin{array}{c}7 \\
42 \\
(26)\end{array}$ & $\begin{array}{l}25 \\
29 \\
(7)\end{array}$ & $\begin{array}{c}31 \\
40 \\
(29)\end{array}$ & $\begin{array}{c}18 \\
39 \\
(17)\end{array}$ & $\begin{array}{c}41 \mathrm{a} \\
41 \\
(14)\end{array}$ \\
\hline 5 April & $\begin{array}{l}\text { Zero } \\
\text { Positive } \\
\text { No bees } \\
\text { with zero } \\
\text { spores }\end{array}$ & $\begin{array}{l}30 \\
37 \\
(9)\end{array}$ & $\begin{array}{c}42^{\mathrm{a}} \\
40 \\
(16)\end{array}$ & $\begin{array}{c}3 \\
35 \\
(38)\end{array}$ & $\begin{array}{l}18 \\
31 \\
(4)\end{array}$ & $\begin{array}{c}9 \\
39 \\
(19)\end{array}$ & $\begin{array}{c}38^{b} \\
38 \\
(11)\end{array}$ & $\begin{array}{c}28.5^{\mathrm{a}} \\
36.5 \\
(2)\end{array}$ \\
\hline
\end{tabular}

\footnotetext{
a No significant difference between the survival curves for the zero-count bees and the positive-count bees. For all other cages, the zero-count bees had significantly shorter lives than the positive-count bees (log-rank test, $P<0.05$ ). b Survival distribution estimate for dosed bees significantly lower than that for control bees (log-rank test, $P<0.05$ ), even though the $L T_{50}$ s are identical.
}

been because they did not become infected with $\mathrm{N}$ apis, (either dosing technique failure or bees refractory to infection) or because they were infected, but carried spore loads that were below the level of detection with the haemacytometer method used. Logrank tests to compare survival curves for these zero-count dosed bees with the corresponding curves for control bees (from the same colony and sampling date) showed that the zero-count bees had significantly poorer survival than the controls in every case but one $(P<0.001$ for all colonies and dates, except for Timaru bees on 7 March). This suggests that dosing these bees with spores had contributed in some way to their deaths and that they were not simply bees that had escaped infection or individuals that had died due to mishandling. Further comparisons, between the zero-count bees and the bees with detectable spore counts from the same cage, showed that, in nearly every case, the zero-count bees had poorer survival than the positive-count bees (table II) $(P<0.05)$. This suggests that dosing newly-emerged bees with $N$ apis may result in a relatively fast death for some bees and a slower demise for the remaining majority. Perhaps some of these young bees were so physiologically immature and vulnerable 
Table III. Mean rates of lifetime accumulation of Nosema apis spores (millions of spores per bee per day) among dosed bees from which positive haemacytometer counts of spores were made. Mean spore loads (millions of spores per bee) are given in brackets.

\begin{tabular}{|c|c|c|c|c|c|c|c|c|}
\hline \multirow[t]{2}{*}{ Date } & & \multicolumn{7}{|c|}{ Colony } \\
\hline & & Rotorua & Nelson & Blenheim & South Otago & Waitomo & Timaru & New Plymouth \\
\hline 7 March & $\begin{array}{l}\text { Rate } \\
\text { Load }\end{array}$ & $\begin{array}{l}1.35 \\
(32)\end{array}$ & $\begin{array}{l}1.99 \\
(75)\end{array}$ & $\begin{array}{l}1.41 \\
(63)\end{array}$ & $\begin{array}{l}0.95 \\
(25)\end{array}$ & $\begin{array}{l}1.27 \\
(63)\end{array}$ & $\begin{array}{l}1.12 \\
(54)\end{array}$ & $\begin{array}{l}2.02 \\
(74)\end{array}$ \\
\hline 21 March & $\begin{array}{l}\text { Rate } \\
\text { Load }\end{array}$ & $\begin{array}{l}0.72 \\
(21)\end{array}$ & $\begin{array}{l}2.12 \\
(72)\end{array}$ & $\begin{array}{l}0.56 \\
(71)\end{array}$ & $\begin{array}{l}1.16 \\
(35)\end{array}$ & $\begin{array}{l}1.21 \\
(46)\end{array}$ & $\begin{array}{l}0.30 \\
(11)\end{array}$ & $\begin{array}{l}1.92 \\
(76)\end{array}$ \\
\hline 5 April & $\begin{array}{l}\text { Rate } \\
\text { Load }\end{array}$ & $\begin{array}{l}1.46 \\
(51)\end{array}$ & $\begin{array}{l}0.99 \\
(40)\end{array}$ & - & $\begin{array}{l}0.92 \\
(29)\end{array}$ & $\begin{array}{l}1.33 \\
(58)\end{array}$ & $\begin{array}{l}0.82 \\
(36)\end{array}$ & $\begin{array}{l}1.27 \\
(45)\end{array}$ \\
\hline
\end{tabular}

that even the ingestion of $N$ apis spores and early events in the infection process were sufficient to significantly shorten their lives. Alternatively, perhaps the gut microflora in some of the bees favoured the development of a fatal septicaemia when the polar filaments of $N$ apis spores began to puncture the gut epithelial cells, such has been shown when caterpillars ingest large doses of spores of microsporidian species such as Vairimorpha necatrix (Fuxa, 1981).

For the dosed bees with positive counts, the rate of accumulation of $N$ apis spores over the lifetime of each bee was estimated by dividing spore count at death by longevity in days (table III). Analysis of variance showed that there were very significant interactions between colony and sampling date $(P<0.00001)$, but with no clear patterns. Thus bees dosed and kept in this manner may die with very variable loads of $N$ apis spores that have no clear relationship to survival time. Because the entire abdomen was examined and not just the ventriculus, spores accumulating in the rectum were included in these counts and thus differences in defaecation behaviour among individual bees may have contributed to this variability. However, although this behaviour was not specifically recorded in the present study, daily inspections of the cages did not reveal any obvious differences in defaecation among the different groups of bees.

In conclusion, the superior ability of some Timaru bees to survive after dosing with $N$ apis suggests that there is some variability in response to this disease among $\mathrm{New}$ Zealand Italian-race bees that could be used to the beekeeper's advantage. As suggested by Rinderer et al (1983), selecting for improved longevity of bees in cages may also bring about an improved response to $N$ apis infection. Further studies are needed, however, to ensure that longer-lived $N$ apisinfected bees are still able to make an effective contribution to their colony's productivity.

\section{ACKNOWLEDGMENTS}

We wish to thank $C$ Triggs of the University of Auckland for statistical analysis and advice. We also thank $R$ Newton for technical assistance and D Yanke of Daykel Apiaries, Kaitaia, New Zealand for assistance and advice on insemination and care of inbred bees. This work was supported by the Foundation for Research, Science and Technology, New Zealand (C06503). 
Résumé - Influence de Nosema apis Zander (Protozoa) sur les abeilles (Apis mellifera ligustica L) consanguines de Nouvelle-Zélande. Afin de mesurer la variation des réactions des abeilles de NouvelleZélande à l'infection par le protozoaire Nosema apis, on a constitué sept colonies d'abeilles consanguines. Chacune d'elles possédait une reine provenant d'une région différente et inséminée artificiellement avec du sperme de mâles, frères de la reine. Les ouvrières récemment écloses, maintenues en cage par groupes de 50 à $32{ }^{\circ} \mathrm{C}$, ont reçu chacune $2 \times 10^{5}$ spores de $N$ apis. Les contrôles ont été faits chaque jour. L'expérience a été répétée trois fois sur une période de 6 semaines à la fin de l'été. La date de l'expérience a eu une action, quoique variable d'une colonie à l'autre, sur la longévité des abeilles témoins : trois colonies n'ont montré aucune différence, pour trois autres les abeilles ont eu une longévité accrue lors de la dernière expérience et pour une colonie provenant de Timaru les abeilles ont vécu plus longtemps lors des deux dernières expériences. L'administration de spores a réduit de façon significative la durée de vie des abeilles de toutes les colonies sauf trois (comprenant celle de Timaru) lors de la première expérience. Les résultats suggèrent que les abeilles qui ont une capacité accrue de survie en cage (comme celles de la colonie de Timaru) peuvent également avoir une meilleure résistance à l'infection par $N$ apis et que la sélection d'une plus grande longévité en cage peut également apporter une meilleure réaction à l'infection par $N$ apis (tableau 1). Dans chaque lot d'abeilles ayant reçu une dose de spores, un certain nombre d'abeilles mortes n'ont pas présenté de spores en quantité détectable. La comparaison des données de survie montre que ces abeilles "zérospores" ont eu une survie significativement plus courte que celle des témoins et la plupart du temps plus courte $(P<0,05)$ que celle de leurs congénères infectées présentant des spores en quantité détectable (tableau II). Cela laisse à penser que l'administration de spores à des ouvrières récemment écloses peut provoquer une mort relativement rapide chez certaines d'entre elles et plus lente chez la majorité. L'analyse de l'estimation du taux d'accumulation des spores de $N$ apis au cours de la vie des abeilles montre des interactions significatives $(P<0,00001)$ entre la colonie et la date d'échantillonnage, mais pas de relation générale claire (tableau III). Dans les conditions de l'expérience, les abeilles ayant reçu une dose de spores peuvent mourir avec des quantités de spores très variables sans relation nette avec le temps de survie.

\section{Apis mellifera / nosémose / consangui- nité / longévité / effet saison}

\section{Zusammenfassung - Auswirkungen von Nosema apis Zander auf ingezüch- tete Honigbienen (Apis mellifera ligustica} L) von Neuseeland. Um Unterschiede der Reaktionen von Honigbienen (Apis mellifera ligustica) auf eine Infektion mit Nosema apis zu bestimmen, wurden 7 unterschiedliche Inzuchtvölker erstellt. Die Königinnen der einzelnen Völker stammten aus verschiedenen Gegenden, und waren instrumentell mit dem Sperma ihrer Brüder besamt worden. Frischgeschlüpfte Arbeiterinnen wurden inviduell mit einer Dosis von $2 \times 10^{5}$ Sporen von $N$ apis infiziert. Sie wurden in Gruppen von 50 Bienen bei $32{ }^{\circ} \mathrm{C}$ in Käfigen gehalten und wurden täglich überprüft. Hierbei wurde die Lebensdauer jeder Biene und die Anzahl von $N$ apis Sporen zum Zeitpunkt des Todes bestimmt. Der Versuch wurde während 6 Wochen am Ende des Sommers in 3 Wiederholungen durchgeführt. Der Zeitraum des Versuches hatte einen Einfluss auf die Lebensdauer der Kontrollbienen, obwohsich der Einfluß von Volk zu Volk unterschiedlich auswirkte: 3 Völker zeigten keine Unterschiede zwischen den 3 Versuchszeiträumen, bei 3 Völ- 
kern lebten die Bienen beim späteren Zeitraum länger und 1 Volk (aus Timaru) erzeugte Bienen mit erhöhter Lebensdauer sowohl in der 2 wie in der 3 Versuchsperiode. In der ersten Periode verkürzte die Infektion die Lebensdauer bei allen Völkern bis auf 3 (einschliesslich Timaru) signifikant. Diese Ergebnisse lassen vermuten, daß Bienen mit einer höheren Lebenserwartung in Käfigen (wie die aus den Timaru Völkern) auch einer Infektion mit $N$ apis besser widerstehen, und daß eine Selektion auf eine erhöhte Lebensdauer von Bienen in Käfigen möglicherweise auch einen erhöhten Widerstand auf $N$ apis Infektionen bedeutet. Jeder Käfig mit infizierten Bienen enthielt eine Anzahl toter Bienen, bei denen keine Sporen nachgewiesen werden konnten. Der Vergleich von Überlebensdaten zeigte, daß diese "Nullwert"-Bienen signifikant kürzer als die Kontrollbienen lebten und meist auch schlechter überlebten, als ihre infizierten Begleitbienen mit nachweisbarer Sporenmenge. Das läßt vermuten, daß die Infektion von frisch geschlüpften Bienen mit $N$ apis für einige Bienen einen relativ schnellen Tod, aber bei der Mehrzahl ein langsameres Sterben bewirkt. Analysen von Schätzungen der Akkumulationsrate von $N$ apis Sporen während der Lebenszeit der Bienen ergaben signifikante Interaktionen zwischen den Völkern und dem Sammeldatum, aber keine klaren Muster. Dementsprechend können Bienen, die in der beschriebenen Weise infiziert und gehalten wurden, bei sehr unterschiedlichen
Sporenbelastungen sterben, die keine klare Beziehung zur Lebensdauer haben.

\section{Honigbienen / Nosema Befall / Inzucht- völker / Lebensdauer / Saisoneffekte}

\section{REFERENCES}

Anderson DL, Giacon H (1992) Reduced pollen collection by honey bee (Hymenoptera, Apidae) colonies infected with Nosema apis and sacbrood virus. J Econ Entomol 85, 47-51

Fries I (1993) Nosema apis - a parasite in the honey bee colony. Bee World 74, 5-19

Fries I, Ekbohm G, Villumstad E (1984) Nosema apis, sampling techniques and honey yield. J Apic Res 23 , 102-105

Fuxa JR (1981) Susceptibility of lepidopterous pests to two types of mortality caused by the microsporidium Vairimorpha necatrix. J Econ Entomol 74, 99102

Goodwin M, Ten Houten A, Perry J, Blackmann R (1990) Cost benefit analysis of using fumagillin to treat nosema. NZ Beekeeper 208, 11-12

Kalbfleisch JD, Prentice RL (1980) Statistical Analysis of Failure Time Data. John Wiley, New York, USA

Malone LA, Giacon HA, Hunapo RJ, Mclvor CA (1992) Response of New Zealand honey bee colonies to Nosema apis. J Apic Res 31, 135-140

Rinderer TE, Sylvester HA (1978) Variation in response to Nosema apis, longevity, and hoarding behavior in a free-mating population of the honey bee. Ann Entomol Soc Am 71, 372-374

Rinderer TE, Collins AM, Brown MA (1983) Heritabilities and correlations of the honey bee: response to Nosema apis, longevity and alarm response to isopentyl acetate. Apidologie 14, 79-85

Sylvester HA, Rinderer TE (1978) Assessing longevity, hoarding behavior, and response to Nosema in honey bees. Am Bee J118, 806-807 